London. This park has cost the country $£ 100,000$. It is surrounded by a very dense population, which terribly needs the park as a place for breathing pure air, apart from all purposes of recreation. If the air is to bc rendered impure by the nearness of the gas-works, then the money of the country will in part have been thrown away, and great injury will result to the population whose benefit was intended. We are sure that no gas-works would have been permitted so near to Thegent's-park or Hyde-park. We sincerely hope that the Lords will not allow a powerful company to be accommodated at the cost of the poor. The Bill is opposed by the Board of Works and by a large and influential minority of the House of Commons. The House appears to have accepted the scheme out of deference to its own committee and not for any liking for it. It is to be hoped that means will be found for prosecuting a determined opposition to the Bill before the House of Lords.

AFren reading through the report of the Scientific Committee on the Cattle Plague we can see no reason why the proposition of treating rinderpest by the injection of whipped and defibrinated blood should not be experimentally tested. The Cattle Plague Commissioners have shown that if the animal sarvive the seventh day of the disease it will probably recover, and that the animal, when it dies, sinks usually from exhaustion and defective nutrition. Dr. Markham, with whom this proposition originates, argues fairly enough that blood, which is food capable of immediate utilization, might help the animal to tide over the time when it is incapable of digesting or assimilating crude food, and he has disposed logically of some theoretical objections which have been urged. The rinderpest is partly extinguished, but it will be long, we fear, before it completely dies out, and it would be a source of regret if the Commissioners, who have power to use any infected animals for experimental purposes, should omit to settle this important question by actual observations. A few experiments would go further than a great deal of discussion.

THE cholera is showing itself all over the world. On the 26th and 27th ultimo more than one hundred deaths occurred at Djeddah. Numerous cases have occurred at Nantes, Rotterdam, and Altenburg. Thirty-five deaths occurred on board the steamer Perurian on her passage from Liverpool to New York, and twenty cases with thirteen deaths in quarantine at the latter port. Another steamer (the Union) from Liverpool had twenty deaths during the voyage. Several cases are stated to have occurred at Liverpool in the most unhealthy part of the town; and one death, after a few hours' illness, at Marsh, near Huddersfield.

A PAPER read at the Academy of Sciences in France estimates the lunatics in France at 84,000-about 1-429th of the whole population. It is stated also that of that number only 358 cases were traceable to intense mental application. In France, says a writer who comments upon this, dissipation, absinthe, and speculation are the predominant causes of the major part of the cases of mental aberration. We apprehend that a similar statement might be justly applied to almost every other country in the world.

\section{THE VACCINATION BILL.}

To the Honourable the Commons of the United Kingdom of Great Britain and Ireland in Parliamont assembled.

The petition of the undersigned, on behalf of the Manchester Medico-Ethical Association,

Humbly sheweth,--That it is of great national importance that universal and compulsory vaccivation shall be established by law.
That a Bill is now before your honourable House which has for its object the attainment of this end.

That the Bill, while highly commendable in its ultimate aim, is defective or erroneous on the following points :-

1. That no public prosecutor of persons evading its enactments is provided for, without whom it is likely to become almost a dead letter.

2. That the rate of remuneration awarded to the public vaccinator is insufficient, more especially as it affects the country medical practitioners.

3. That the compulsory demand (enforced by penalties) from all medical practitioners of professional service to the State without remuneration, is an oppression of one class of the community for the benefit of the rest, and contrary to the whole spirit of British legislation.

4. That no adequate provision is made for a sufficient and periodical supply of vaccine lymph from the cow.

Your petitioners, therefore, humbly pray that your honourable House will pass such a measure as will secure this country from the ravages of so dreadful a malady as small-pox, and that the four points above-named may at the same time obtain your earnest consideration.

And your petitioners will ever pray.

Signed on behalf of the Manchester Medico-Ethical Association,

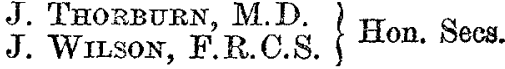

\section{THE MEDICAL A C T.}

To the Editor of Tere LANCET.

SIR,-I beg to forward you a copy of a petition which was presented by Colonel North, M.P. for Oxfordshire, on the 7th inst. Yours obediently,

Banburs, June 8th, 1866.

Artirur B. RYE.

\section{To the Honourable the House of Commons in Parliament} assembled.

We, the undersigned legally qualified practitioners residing and practising in the town of Banbury and its neighbourhood, were by an Act, 2nd August, 1858, required to register under such Act; and upon producing our certificates we, upon a payment of money, were registered accordingly.

Now we complain that by an informality of this Act it is totally inoperative, inasmuch as, by a legal difficulty in the clause No. 40, an unregistered person practising here is allowed to assume a title to which we hold he has no right, inasmuch as the Medical Council under your Act have totally ignored and refused to register it.

Also, seeing that your honourable House is about to pass an Act to prevent unlicensed veterinary surgeons-that is, those who treat the complaints and, as now, preside over the lives of the brute creation-from practising their art without due examination and proper licence, and supposing that the lives of her Majesty's subjects may be held of equal value and entitled to the same protection, we, in our humble capacity, can but urge it as a fair supposition that, in your legislative wisdom, you will so far amend the present Medical Act of 2nd August, 1858, as to afford to those practitioners qualified under it that protection which they have expected by a registration under its requirements, which it was no doubt intended to supply, but which from its imperfect construction it has hitherto so signally failed to effect.

And your petitioners will ever pray.

(Signed) ARThUR B. RYe, F.R.C.S., Bankury.

JoHN GRIFFIN, M.D., M.R.C.S., do.

Sherman Chesteritay, M.R.C.S.

Clarence L. Pemberton, Banbury.

EDward Franex, M.R.C.S., do.

RichaRd GRIMBLY, M.R.C.S., do. W. W. HyDE, M.R.C.S., Bloxham. John Colmgrave, M.R.C.S., do. J. MacGreal, M.R.C.S., Alkerton. W. T. DodGLAS, M.R.C.S., Banbury. R. S. WISE, M.D. do. Geo. Fayrer, M.D., Henley in Arden. Tromas Clarke, M.R.C.S., Banbury.

* Medical practitioners in all parts of the kingdom might with advantage adopt a suitable form of petition in favour of the Medical Acts Amendment Bill, and forward it to their respective representatives, with an urgent request for support. 